\title{
Altering Authorships: Absences and Presences of Authors in Contemporary Culture
}

\author{
Edyta Lorek-Jezińska* \\ Nelly Strehlau* \\ Katarzyna Więckowska* \\ lorek@umk.pl \\ strehlau@umk.pl \\ Katarzyna.Wieckowska@umk.pl \\ *Nicolaus Copernicus University in Toruń
}

Received 28 December 2021; accepted 28 December 2021; published 29 December 2021.

\begin{abstract}
This article serves as an introduction to the anthology devoted to the study of altering authorships in contemporary literature and culture. Drawing attention to the influence of Roland Barthes's and Michel Foucault's works on the author and authorship, the essay emphasises the importance of the context of both production and reception in determining the authority over and responsibility for the literary/cultural text. By altering authorships we mean various processes of diffusing authorial authority, on the one hand, and reassessing authorship for alternative authors, on the other. Conceptualised as authorial absences and authorial presences, the acts of questioning and transforming the practices of authorship and the process of (re)introducing alternative or marginalised authors discussed in the article testify to the continuing significance of the authorship debate. In this context, authorship can be approached as "a living absence" (Berensmeyer et al.), opening space for disruptions, dispersals, redefinitions, negotiations and reconciliations of authorial presences.
\end{abstract}

Keywords: authorship; authors; authorial practices; transhumanism; gender studies; performativity

\section{Introduction}

Recent decades have witnessed a growing interest in issues connected to authoring, authorship, and cultural and literary authority, as evidenced by numerous publications examining the status of authors and readers, such as Seán Burke's The Death and Return of the Author (1998; originally published in 1992), and by the rise of "authorship studies" (cf. Berensmeyer et al., 2019). Strongly influenced by Roland Barthes's essay on "The Death of the Author" (1988; originally published in 1967) and Michel Foucault's description of the author function in his "What is an Author?" (1988; originally published in 1969), critical studies of authorship have redefined the place of the author and the reader in the process of interpretation and negotiation 
of meanings, questioned the traditional discourses of authorship and decentralised authorial practices. For most critics, the "death" of the Author freed scholarship from the "tyranny" of biography, unity of meaning and authorial control, and prepared the ground for the emergence of alternative authors, decentred, multiple and previously marginalised, just as it created the space for the appearance of new kinds of active readers. For others, however, this "death" meant the denial of agency to groups that were only just beginning to have their claim to authorship recognised, uncannily silencing the subversive potential of non-hegemonic authors (cf. Mary Eagleton's [2005] discussion on the relation between the death and birth of the author and women's writing). While Barthes's work has unquestionably contributed to the dynamic processes of negotiating authorship between multiple authors and readers, Foucault's essay has opened the way for historicising authorship, drawing attention to practices of ownership and the discursive construction of authors and readers. As a result, contemporary authorship studies are no longer limited to the study of the author's biography or the attempt to uncover their intentions, but focus on the examination of the social structures and media technologies that shape the author function at a given point in time, thereby also determining the role of the reader and the status of the text. With the author neither fully "dead" nor convincingly present and with new textual practices and forms of dissemination, contemporary critical studies face new challenges and "are now at the point of reevaluating authorship as a living absence” (Berensmeyer et al., 2012, p. 23).

The articles comprising this anthology examine the idea of "authorship as a living absence" by focusing on two processes of altering authorships: diffusing authorial authority and reassessing authorship for alternative authors. Altering authorships thus refers to the act of questioning and transforming the concept and practices of authorship, on the one hand, and the process of the (re)introducing alternative and marginalised authors, on the other. The research materials examined in this volume range from experimental fiction and auto-fiction to independent film and television series to photography. The anthology presents a cross-section of interdisciplinary theoretical approaches, spread between literary and cultural studies and referring to other branches of the humanities and social sciences, with particular attention given to posthumanism, gender and queer studies. Although in geographic terms the volume is much embedded in Western European and American cultures, the authors discuss also the development of lesbian literature in Poland, Australian poetry and recent publications in Polish authorship studies, and investigate counter-hegemonic and centripetal strategies within this large and heterogeneous field.

The articles gathered in the first section of this anthology explore various aspects and types of "authorial absences," by which we mean the processes whereby traditional authorship is evacuated, dispersed or substituted by other non-authorial entities or by readers. Focusing on new materialism, posthumanist authorships and agency, materiality, multimodality and embodiment of texts, as well as self-erasure and deconstructions of autobiography, the articles in this section question human authority and anthropocentric control, redefining agency and opening alternative spaces for negotiating meaning. The texts in the second section, entitled "Authorial presences," examine various acts of re-instating and reconciling authorial control. The essays included in this part discuss texts and practices of reclaimed and claimed authorships in women's art, television and film, and lesbian literature, thereby rereading feminism, women authors' agency and authority. In doing so, they expose both the contradictions and 
contiguities of Barthes's essay, by underlying the importance of the author question for women writers and artists and exposing the dangers and violence of taking over authority together with authorship.

\section{Authorial Absences}

In the article opening the section on "Authorial absences," entitled "Authoring the Readerly Experience: On Materiality, Multimodality and Singularity of Literature in Nicola Barker's H(a)ppy," Tymon Adamczewski explores the connections between experimental writing, authorial control, and freedom of interpretation. As a novel "concerned primarily with the destruction of narrative" (Clark, 2017), H(a)ppy provides fertile ground for asking whether modifications of layout, typography, typeface, and graphic design should be seen as synonymous with interpretative openness or a non-authoritative response (Adamczewski). Multimodal texts, as Alison Gibbons argues, "ask readers to cognize and integrate meaning from the creative synthesis of word, image, and tactility" and as such call for "a more performative and engaged understanding of the reader's role" (2012, p. 433). Accordingly, Adamczewski's discussion highlights the question of authority of the material text and the play of resistance and control in Barker's book referring to the theories of authorship presented by Roland Barthes and Michel Foucault, the subversive politics of postmodernist literature, the notions of difference and writing by Jacques Derrida, and the concept of deconstructive veering by Nicholas Royle, among others. This nuanced and at times provocative reading of the multimodal text of $H($ a $)$ ppy concludes with the proposal to see such type of writing as "a performative inscription" or event, "an experience which is rooted in the page but which grows to take place beyond its borders, in the space of literature in which the reader actively participates" (Adamczewski), yet which also uncannily evokes the author's controlling and manipulative presence.

Adamczewski's exploration of performative writing is followed by Michał Kisiel's "Stories of White World: Samuel Beckett's Posthuman Authorship," in which he approaches short fiction by Samuel Beckett from the perspective of new materialism. Referring to the peculiar dispersal of the authorial figure untypical for Beckett's earlier work, Kisiel proposes a "thought-experiment" to conceptualise authorship in Beckett's late fiction as "posthuman authorship," by which he means "the uncanny capacity of Beckett's texts to undermine the subjectivities of both the human author and the human reader [...] in favour of the constellations of matter and meaning - if not textural and textual transformations - as if they aimed to constitute themselves on their own terms." Focusing on the later short fiction by Beckett, in particular "The Lost Ones," "Lessness," and "Ping," yet taking detours to his earlier works, such as Krapp's Last Tape, Embers or The Unnameable, Kisiel examines Beckett's "materialist works" by foregrounding the materiality of language and its exhaustion. Kisiel considers these aspects in the context of new materialist theories, some of which have already found their way into Beckett's scholarship. Highlighting Karen Barad's major contribution to the development of other materialist theories, Kisiel comments on, among others, Serenella Iovino and Serpil Oppermann's concept of storied matter (2012) and the notion of matterphorics 
(Gandorfer and Ayub, 2021), both of which redefine radically the type of attentiveness inherent in the text and demanded from the reader and illuminate some of the strategies of Beckett's later texts.

Katarzyna Ostalska's "Embodiment as a Performatively Posthumanist Form of Material Authorship in The Lesser Bohemians by Eimear McBride" adopts a new materialist perspective to focus on matter and processes of mattering in the Irish writer's work. The Lesser Bohemians is McBride's second novel, and it continues the experimentation with language and form of A Girl Is a Half-Formed Thing (2013), described by John Sutherland as a kind of writing for which "we don't, as yet, have a term" (2014). Ostalska reaches to feminist embodiment and posthumanist critical theories as well as new materialism to find terms to discuss the "material re-groupings of diverse embodiment types" (Ostalska) depicted in the novel and to analyse the mattering of embodiment through "authorial, formative, agentive processes on the level of corporeality, perception and self-creation" (Ostalska). Stressing the experimental character of the novel, the author reads McBride's fiction as substituting "early twentieth-century psychology of the stream of consciousness" by "imagery derived from the twenty-first-century science." The key concept in the analysis is Karen Barad's notion of matter as agentive and her understanding of posthumanist performativity as "one that incorporates important material and discursive, social and scientific, human and nonhuman, and natural and cultural factors," and that "is linked not only to the formation of the subject but also to the production of the matter of bodies" (Barad, 2018, p. 226). Building her approach on the work of Rosi Braidotti, Katherine Hayles, and Donna Haraway, the author convincingly presents the narrator's material embodiment as "a living matter" interacting with other (organic and non-organic) matter, and portrays agency as "not an attribute but the ongoing reconfigurings of the world" (Barad, 2018, p. 232), perhaps best captured by the notion of sympoiesis, which Ostalska, following Haraway, describes as a process of making worlds and selves that always takes place in company, with other matter(s) (Ostalska).

A different aspect of authorial absence is explored in "The Author Disappearing? Authorial 'Surrogates' and Contemporary Self/Other-Writing in Selected Works by Annie Ernaux, Édouard Louis, and Rachel Cusk" by Robert Kusek, where he discusses examples of recent autobiographical writing that he sees as "manifestation[s] of the crisis of the auto/biographical self and form." Kusek shows that in the decades since its conception in 1977, autofiction has become prominent in critical literature and as a mode of writing. The authors whose work he discusses, Annie Ernaux, Édouard Louis and Rachel Cusk, simultaneously participate in the autobiographical boom of recent decades and, through their work, contest the generic classifications and boundaries of autofiction, a literary form that seems to be particularly significant for authorial revival. Kusek describes various manners in which their ostensibly autobiographical novels challenge the notion of the author. He argues that the use of third person and first person plural instead of author-identified "I" in Ernaux's The Years (2018 [2008]) serves to undermine the very notion of individual subjectivity. Next, Kusek analyses the way in which Louis's The End of Eddy is preoccupied with the transformation or even eradication of the narrator's erstwhile identity: for Édouard to come into being, Eddy must be radically erased, to exist only as "a fictional creation." Finally, the article turns to Cusk's trilogy (Outline, 2014, Transit, 2016 and Kudos, 2018), a work whose writer-protagonist can be seen as "renounc[ing] all personal agency and narrative authority" (Schwartz, 2018), and that Kusek describes as 
both fictionalising and "compartmentalis[ing]" the authorial self. If "[a]utobiography and the concept of the author as sovereign subject over a discourse are products of the same episteme" (Sprinker, 2014, p. 325), then such a destabilisation of autobiography can be seen as a productive and foundational gesture, an attempt at finding "a new self-writing poetics" (Kusek), potentially resulting in new notions of what authorship means.

A further complication of the notion of authorship as singular is explored by Patrick Gill in his article entitled "'Stick to facts': Author Figures and Textual Authority in Robinson Crusoe and the Twentieth-Century Robinsonade," where he argues that the Robinsonade is by definition always concerned with "the question of authorship and textual authority, even where an author figure is omitted" (Gill). Being read with "a double awareness of both fictiveness and a basis in the "real"" (Hutcheon, 1988, p. 107), the genre prototype - Robinson Crusoe by Daniel Defoe - can be approached, as Gill proposes, as a text written not by one but two authorial figures: "contemporary" and "retrospective" Robinson, with one of them affective and experiential and the other - "sense-making" and controlling. With its commitment to selfreferentiality and metafictionality, the twentieth-century Robinsonade, like one of its significant examples - Foe by J.M. Coetzee - discusses the authority of the storyteller, who can, as Linda Hutcheon comments in her study of historiographic metafiction, "silence, exclude, and absent certain past events - and people" (p. 107). Gill highlights how Coetzee's Foe, in the struggle between two authorial figures, creates space for the possibility of the silent character of Friday to take over, thus continuing the genre's metafictional concerns. The analysis of Muriel Spark's Robinson conducted by Gill focuses on the dispersal of the authorial figure and on "authorial uncertainty." The effect it produces, compared by Craig (2019) to "generic instability" caused by the "evaporation" of reality in the narration (p. 60), is, as Gill writes, "one of a pervasive, lasting unknowability rather than of seemingly random events retrospectively interpreted with authority." The last Robinsonade examined by Gill is J.G. Ballard's Concrete Island (1974), which he describes in terms of "authorial absence." According to Gill, Ballard's novel presents a possibility of "human agency" taken over by the built environment, whose effect is "frightening" as it is devoid of any discourse.

\section{Authorial Presences}

The part dedicated to "Authorial presences" begins with Katarzyna Lisowska's article entitled "Lesbian Writing and Authorship in the Polish Literary Tradition: How to Define the Nondefined?", which constitutes an attempt at synthesising existing scholarship on queer women's literature and status as authors in the field of Polish literary studies. Lisowska's account is comprehensive and nuanced, inviting attention to various factors posing a challenge to formulating a cohesive notion of Polish lesbian poetics or a definitive historical account of Polish lesbian literature. The author notes the problems arising from the relative scarcity of attention paid in the past to queer literature by women in contrast to that afforded to male homoeroticism. This problem may be seen as an example of "lesbian erasure," wherein the difficulty of "reclaim[ing] a homosexual subject" in general is compounded by "the tendency of historians simply to ignore women" (Wilton, 1995, p. 60): the lesbian author is difficult to locate and reclaim. Lisowska's summary of the history of Polish texts by and about queer women emphasises gaps between its origins during fin de siècle, its continuation in the interwar period 
and finally, recent developments, starting after 1989. As she points out, while a modernist tradition, prominent in Western queer writing, can be traced in Polish gay literature, the same cannot necessarily be said of lesbian writing, which leads to the conclusion that "the theory of lesbian writing $[\ldots]$ might have even preceded literature" in the Polish context. Finally, Lisowska reflects on the difficulties posed by essentialist or biographical definitions and descriptions of lesbian literature, noting disparate approaches to the subject among scholars. Her proposal is to see Polish lesbian literature as inflected by a queer perspective, which facilitates "overcoming the binary vision of sexuality" and allows for a focus on lack or provisionality as positive and productive traits. Given the relative scarcity of attention paid to such subjects as queer literature in "Slavonic and East European studies" in English, which more commonly highlight "post-communist transformations" (Kulpa and Mizielińska, 2012, p. 19), Lisowska's article contributes to re-situating Polish queer literature and makes its study accessible to international readership.

In her article "'I'm not trying to be Tolstoy': Women's Authorship in Selected Television Series," Nelly Strehlau combines an overview of the history of television authorship and the role gender has played in the construction of the figure of the television auteur with an analysis of three series about women writers. As "[n]o concept of gendered media representation can function without a concept of authorship" (Humm, 1997, p. 92), it is impossible to perceive the diegetic authors without considering the shows' creators, who are frequently (mis)identified with the protagonists of their narratives. Strehlau demonstrates similarities between the writer characters of Sex and the City (1998-2004), Girls (2012-2017) and I May Destroy You (2020), as all three achieve comparable career milestones and engage in life-writing and selffictionalising in a way that may be perceived as ethically compromised. Furthermore, she points to the prominence of autobiographical readings of the latter two series, showcasing the way in which "authorial ethos remains central to textual interpretations" (Busse, 2013, p. 50) in contemporary reception of television series. Strehlau also notes that the three series distance themselves from their writer protagonists, emphasising their flaws and satirising their efforts. Nevertheless, both Girls and I May Destroy You simultaneously depict the work of their protagonists as worthy of serious attention, which can be seen as an attempt by Lena Dunham and Michaela Coel, respectively, to make their own claims to the auteurial title, highlighting their artistic ambitions.

Magdalena Cieślak's “Cultural Authority and Gender Politics - Christine Edzard's The Children's Midsummer Night's Dream" addresses a different set of readers and raises questions about cultural authority and its negotiations in children's version of Shakespeare's play directed by Christine Edzard. With its dispersal of adult authority and liberation from the conventions and constraints of professional acting, Edzard's film belongs to what Donald Hedrick and Bryan Reynolds call "a transversal territory" within "Shakespace" - "an ambiguous space that makes possible and in fact encourages alternative opportunities for thought, expression, and development" (2000, p. 9). One of the problems addressed by Magdalena Cieślak is to what extent the children's version is actually theirs, considering the degree to which their acting is "motivated, orchestrated and directed by adults and their institutionalized ideologies" (Cieślak). Although the children were actively engaged in the decision making process, by choosing, for example, the characters they play, costumes or preparing the set (Stockman, 2004, p. 118) and forming their interpretations of scenes and relationships (Stockman, 2004, 
p. 121), whether they were able to independently and intentionally make those choices can be doubted. Exploring the gaps between the text and the children's experience and awareness, Cieślak's article discusses the complex and sometimes problematic relation of the children participants to the matters of sexuality and eroticism present in Shakespeare's Midsummer Night's Dream. In addition to the difficulty of navigating in the nuanced gender politics of the play, the children also experience the difficulties with memorising and rendering Shakespeare's text, making their performance far from spontaneous and unrestrained. As a result, despite its experimentality and novelty in cooperating with amateur actors and the creative freedom given to children in the production process, Edzard's film is approached as "a troubling take on Shakespeare's iconic romantic comedy" (Cieślak).

The shift of perspective from seeing art as an act of authorial disappearance to art as a means of regaining the creator's presence is discussed by Anna Backman Rogers in her "Not Because My Heart is Gone; Simply The Other Side: Francesca Woodman's Relational and Ephemeral Subjectivity at the Limit of The Image," which explores the connections between art, (self-)authorship, and subjectivity in the American artist's work. In contrast to other critics studying Woodman's oeuvre, Rogers does not frame her analysis within the photographer's tragic personal history, but reads her art as a meditation on the (im)possibility "of capturing subjectivity as presence" (Rogers). Seen from this perspective, Woodman's work is not "the externalisation of psychic pain" or "a self-destructive iteration" (Rogers), but an attempt to examine what it means to be present for oneself and for others, and to present oneself as a subject for and through others. The analysis of the ways in which Woodman's photographs "dramatize and complicate the moment in which we come into being for someone or something else" (Rogers) is based on Judith Butler's conceptualization of subjectivity as constituted by terms that "are, from the start, outside oneself, beyond oneself in a sociality that has no single author (and that radically contests the notion of authorship itself)" (Butler, 2004a, p. 1). Woodman's work, as Rogers argues, "renders clear the vulnerability, mutability and ephemerality of subjectivity" and presents the subject as embodied: "the photographic body" is "a liminal body in movement that is always on the cusp of becoming other" (Rogers), demonstrating that "we are, as bodies, outside ourselves and for one another" (Butler, 2004b, p. 27). In her captivating reading of Woodman's photography, Rogers draws attention to the ideological dimension of the gaze through which the female subject and her body come into being, and complicates the notion of agency and authoring by claiming that the artist's "work functions not as an auteurist statement, but investigates the always already ideologically laden ways in which a being becomes something rather than nothing for someone else" (Rogers).

\section{Authorship Across Time and Space: Book Reviews}

Two books discussed in the reviews section share preoccupations with the changing conceptualisations of authorship across time and space and engage in a debate on the legacy of the myth of the author and authorship. In "The Pasts and Futures of Authorship," Paulina Szczepaniak and Dawid Smyk discuss Authorship: Commercializing of Literature and the Phantasm of the Authorial Subject [original title: Autorstwo. Urynkowienie literatury i fantazmat podmiotu autorskiego] by Aldona Kobus, published in 2021 by Nicolaus Copernicus University Press. Kobus's book is in many respects a pioneering study, as it introduces to Polish readers 
the history of Western discourses on authors, authorship and authority, including the Romantic model of the author as genius and the commercialisation of authorship, the position of women writers on the 19th-century literary market, and the 20th-century rewritings of the author function in poststructuralist and feminist theory. The last part of the book offers a powerful deconstruction of the concept of the author as a solitary figure and presents the idea of authorship as a collaborative process - a claim which, as Smyk and Szczepaniak convincingly argue, should be read in reference to other publications by Kobus, especially her work on fandom. Smyk and Szczepaniak's review of Kobus's book offers a comprehensive and informative summary of the main concepts and critical positions presented in the book, putting the work in the larger context of contemporary discussions of authorship.

The book examined in the second review is Concrete Horizons: Romantic Irony in the Poetry of David Malouf and Samuel Wagan Watson by Ruth Barratt-Peacock, published in 2020 by Peter Lang. Ruth Barratt-Peacock explores the continuities and disruptions of influence, by tracing the link between twentieth-century Australian poetry and Romantic irony inherited from European Romanticism. In her review entitled "The Self and the Other beyond Landscape and Language," Bernadetta Jankowska focuses on the significance of Romantic irony for expressing the gaps and contradictions in poetic language and imagery representing the Australian experience. Revealing the limited or inadequate resources of the English language to present the otherness of Australia, Romantic irony, as Barratt-Peacock argues, makes it possible to express the hybridity of identities and their complexities without resorting to definite answers. Jankowska's review offers an overview of significant ideas and motifs described by Barratt-Peacock in her examination of a selection of several dozen poems by David Malouf and Samuel Wagan Watson. Referring to the Aboriginal Gothic, among many other concepts discussed by Barratt-Peacock in her book, Jankowska problematises the complex nature of postcolonial entanglements of Australian subjects and landscapes, and their positioning vis-àvis Aboriginal and European cultures.

\section{Conclusion}

In a foreword to a collection of critical essays on his work, tellingly titled "On Being the Subject of a Conference or, What Do I Know?", Tom McCarthy describes an author as someone who is not so much a ghost, but "more like a by- or waste-product of the work, and of literature in general” (2016, p. 2). ${ }^{1}$ Contrary to McCarthy's claim, the articles collected in this anthology prove that authors do play a significant role in the production of their works, although in ways different from those described in traditional criticism. Focusing on various kinds of texts and authors, and on practices of dissolving and consolidating authority, the articles present authorship as a complex practice shaped by multiple acts of authoring and driven by a constant struggle for control between various agents, not all of whom are human. Overall, they demonstrate

\footnotetext{
${ }^{1}$ Ingo Berensmeyer, Gert Buelens, Marysa Demoor refer to McCarthy's foreword in their introduction to The Cambridge Handbook of Literary Authorship (2019, p. 6).
} 
that authorship should be seen as performative, constituted by repeated acts that - to use Berensmeyer, Buelens, and Demoor's apt description - "are enabled and constrained by social norms and different media configurations" and that should be studied "in the context of concrete cultural manifestations (or performances) [...], taking into account material, discursive or institutional conditions and constraints" (2012, pp. 10, 14).

\section{References}

Barad, K. (2018). Posthumanist performativity: Toward an understanding of how matter comes to matter. In C. Åsberg and R. Braidotti (Eds.), A feminist companion to the posthumanities (pp. 223-239). Cham: Springer.

Barthes, R. (1988). "The death of the author." In D. Lodge (Ed.), Modern criticism and theory: A reader (pp. 167-172). London: Longman.

Berensmeyer, I., Buelens, G., \& Demoor, M. (2012). Authorship as cultural performance: New perspectives in authorship studies. Zeitschrift fur Anglistik und Amerikanistik 60(1), 5-29.

Berensmeyer, I., Buelens, G., \& Demoor, M. (2019). Introduction. In I. Berensmeyer, G. Buelens and M. Demoor (Eds.), The Cambridge handbook of literary authorship (pp. 1-10). Cambridge: Cambridge University Press.

Burke, S. (1998). The death and return of the author: Criticism and subjectivity in Barthes, Foucault and Derrida. Edinburgh: Edinburgh University Press.

Busse, K. (2013). The return of the author: Ethos and identity politics. In J. Gray and D. Johnson (Eds.), A companion to media authorship (pp. 48-68). Hoboken: Wiley-Blackwell.

Butler, J. (2004a). Undoing gender. New York: Routledge.

Butler, J. (2004b). Precarious life: The powers of mourning and violence. London and New York: Verso.

Clark, A. (2017, August 15). H(a)ppy by Nicola Barker review - life in a world without stories. The Guardian. https://www.theguardian.com/books/2017/aug/15/happy-nicola-barker-reviewworld-without-stories.

Craig, C. (2019). Muriel Spark, existentialism and the art of death. Edinburgh: Edinburgh University Press.

Eagleton, M. (2005). Figuring the woman author in contemporary fiction. Basingstoke: Palgrave Macmillan.

Foucault, M. (1988). "What is an author?” In D. Lodge (Ed.). Modern criticism and theory: A reader (pp. 197-210). London: Longman.

Gandorfer, D. \& Ayub, Z. (2021). Introduction: Matterphorical. Theory \& Event, 24 (1): 2-13.

Gibbons, A. (2012). Multimodal literature and experimentation. In J. Bray, A. Gibbons and B. McHale (Eds.), The Routledge companion to experimental literature (pp. 420- 434). London: Routledge. 
Hedrick, D. \& Reynolds, B. (2000). Shakespace and transversal power. In Hedrick, D. and B. Reynolds (Eds.), Shakespeare without class: Misappropriations of cultural capital (pp. 3-47). New York \& Basingstoke: Palgrave.

Humm, M. (1997). Feminism and film. Edinburgh: Edinburgh University Press.

Hutcheon, L. (1988). A poetics of postmodernism: History, theory, fiction. London: Routledge.

Iovino, S. \& Oppermann, S. (2012). Material ecocriticism: Materiality, agency, and the models of narrativity.ecozon@, Vol. 3, No. 1: 75-91. https://doi.org/10.37536/ECOZONA.2012.3.1.452

Kulpa, R., \& Mizielinska, J. (2012). Guest editors' introduction: Central and Eastern European sexualities "in transition". Reflections on queer studies, academic hegemonies, and critical epistemologies. Lambda Nordica, 17(4), 19-29. Retrieved November 26, 2021 from https://www.lambdanordica.org/index.php/lambdanordica/article/view/359.

McCarthy, T. (2016). Foreword: On being the subject of a conference or, what do I know? In D. Duncan (Ed.), Tom McCarthy: Critical essays (pp. 1-2). Canterbury: Gylphi.

Schwartz, A. (2018, November 18). "I don't think character exists anymore": A conversation with Rachel Cusk. The New Yorker. https://www.newyorker.com/culture/the-new-yorker-interview/i-dont-think-character-exists-anymore-a-conversation-with-rachel-cusk.

Sprinker, M. (2014). Fictions of the self: The end of autobiography. In J. Olney (Ed.), Autobiography: Essays theoretical and critical (pp. 321-342). Princeton: Princeton University Press. https://doi.org/10.1515/9781400856312.321

Stockman, O. (2004). Producing the Children's Midsummer night's dream (2001): A discussion with Olivier Stockman. In S. Hatchuel and N. Vienne-Guerrin (Eds.), Shakespeare on screen: The midsummer night's dream (pp. 115-128). Rouen: L'Universite de Rouen.

Sutherland, J. (2014, June 6). Eimear McBride's novel doesn't fit any terms we use to categorise writing. The Guardian. https://www.theguardian.com/commentisfree/2014/jun/06/eimearmcbride-novel-terms-writing-consciousness.

Wilton, T. 1995. Lesbian studies: Setting an agenda. London: Routledge.

Edyta Lorek-Jezińska is associate professor in the Department of Anglophone Literature, Culture and Comparative Studies at Nicolaus Copernicus University, Toruń, Poland. Her current research centres on disability studies and drama, trauma studies and hauntology as well as performance, art, site and archive. She is the author of Hauntology and Intertextuality in Contemporary British Drama by Women Playwrights (2013, Toruń) and co-editor of the special issue of Avant on Listening to the Urbanocene. People - Sounds-Cities (2020).

Nelly Strehlau is employed as assistant professor in the Department of Anglophone Literature, Culture and Comparative Studies at Nicolaus Copernicus University in Toruń. Her PhD analysed feminist and postfeminist hauntings in American television series about women lawyers. She is the author of multiple articles dedicated to American and British television, published in English and Polish. Her current research encompasses interrogation of popular culture from the perspective of affect studies and hauntology, with a special interest in women's authorship and (post)feminism. 
Katarzyna Więckowska is associate professor in the Department of Anglophone Literature, Culture and Comparative Studies at Nicolaus Copernicus University, Toruń, Poland. Her research interests include the contemporary novel in English, ecocriticism, feminist criticism, studies of masculinities, and hauntology. She is the author of Spectres of Men: Masculinity, Crisis and British Fiction (2014), editor of The Gothic (2012/2020) and co-editor of Haunted Cultures / Haunting Cultures (2017). 